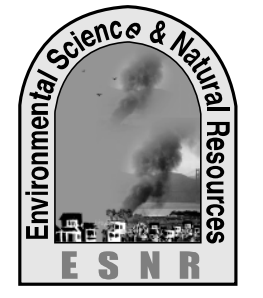

\title{
Efficacy Test of Growth Promoters From Some Pharmaceutical Companies on Koi (Anabas Testudineus) Fish
}

\author{
M. M. Rahman, M. T. Zaman and A. M. Islam
}

Department of Aquaculture, Bangladesh Agricultural University, Mymensingh

\begin{abstract}
A study was conducted to determine the efficacy and performance of three most commonly used growth promoters from different pharmaceutical companies on climbing perch (Anabas testudineus) fish. Experiment was done in the wet lab of Aquaculture Department, Bangladesh Agricultural University, Mymensingh. A total 10 newly constructed aquarium were used for this experiment. 200 fish were used for this study. Numbers of growth promoters were 3, from different pharmaceutical companies. The growth promoters were:-Nutricell-Aqua from "EON"COMPANY; Aqua-boost from "NOVARTIS"COMPANY; and Hepaprotect-Aqua from "RENATA"COMPANY were used in separated nine (9) aquarium at recommended dose, lower dose, higher dose respectively. A single aquarium was used for the control. Pellet feed were used with $20 \%$ body weight for each aquaria except control because only feed were used in the control to compeer the growth performance of other drug. Dose of Nutricell-Aqua were given as $10 \mathrm{mg}, 15 \mathrm{mg}, 5 \mathrm{mg} / 20 \mathrm{~g}$ feed/day. Dose of Aqua-boost were given as $10 \mathrm{mg}, 15 \mathrm{mg}, 5 \mathrm{mg} / 20 \mathrm{mg}$ feed/day. Dose of Hepaprotect-aqua given as $40 \mathrm{mg}, 60 \mathrm{mg}$ and $20 \mathrm{mg} / 20 \mathrm{mg}$ feed/day. The feeding period was conducted for 20days. Among the three growth promoters Aqua-boost from Novartis Company at higher dose and Hepaprotect-aqua from Renata Company at recommended dose showed good result around $90.50 \mathrm{~g}$ and $40.75 \mathrm{~g}$. Weight gains were recorded. But Nutricell-aqua from Eon company's performance were very poor compared with others drug.
\end{abstract}

Key Words: Aqua-Medicines, Dosage, Drug, Growth promoter, Performance, Pharmaceutical Companies

\section{Introduction}

Growth promoters are chemical and biological substances which are added to fish's food with the aim to improve the growth of fishes. It is necessary for fattening and improving the utilization of food and in this way realizes better production and financial results. Their mechanism of action is varies. Positive effect can be expressed through better appetite, improved feed conversion, stimulation of the immune system and increased vitality, regulation of the intestinal micro-flora, etc. Fish disease is also very alarming factor. In aquaculture as in all foods production sector one of the external inputs required for successful fish production is aqua medicine. Aqua medicines are indeed essential ingredients to successful aqua culture, which has been used in various forms for centuries (Subasinghe et.al.1996).Use of aqua medicine in aquaculture system for various purposes is widely recognized. They are essential components in pond construction, health management, soil and water management, enhancement of natural aquatic productivity, transportation of live organism, feed formulation, manipulation and enhancement of reproduction, growth promotion and processing value enhancement of final product (alderman et.al.1994,GESAMP,1997) Forty pharmaceutical companies have been recorded to market their products. Most of the products have been imported from different countries like USA, Thailand, Malaysia, Belgium and China (Islam, 2010). The effectiveness of the aqua-medicine was might being reduced due to mixing of other final ingredients by the local traders. Most of the farmer's dose not knows the appropriate dosage and method of application. It has been recognized that farmers were using those aquamedicine without knowing their efficacy. This is due to lack of information regarding the present status and consequence of aqua-medicine using in aqua-healthdevelopment. Considering the above facts, the present study was conducted to attain the following objectives:-

- To determine the actual efficacy of some selected growth promoters.

- To know the actual dose and dosage of drugs for improving the growth of fish.

- To know the purpose of using appropriates dose and methods of application of various aquamedicines.

- To identify the problems which are associate with the recommended dose of aqua-medicine?

- To determine the existing problems in using the drugs and their remedy. 


\section{Materials and Methods}

\section{Study areas}

The study was carried out at a well decorated wet laboratory. This laboratory was situated near the Aquaculture Department, Faculty of Fisheries; in Bangladesh Agricultural University, Mymensingh. Ten (10) aquariums were used for this experiment.

\section{Aquarium description}

The experiment was conducted within 10 well constructed and water proofed aquarium. Length of individual aquarium was $25 \mathrm{inch}$, width of individual was 12inch and height of individual aquarium was 15inch. Total water holding capacities of individual aquarium were 45 liter. The entire aquariums which are used in this experiment were covered by a synthetic net.

\section{Selected feed used for experiment}

The study was conducted by the artificial fish feed which were suitable for koi(Anabas testudineus) culture. Especially pellet feeds were used which was sinking or semi-sinking. The name of feed was "Bishas feed" from a well developed fish feed company. Amount of feed required for each aquarium were $20 \mathrm{~g} /$ day. Extra feeds were exchanged by removing water. The colors of feeds were "gray". Total amount of feed required for this experiment were $20 * 20 * 10=4 \mathrm{~kg}$. Proximate composition of feeds was estimated through the technology lab in Bangladesh Agricultural University, Mymensingh.

The proximate compositions of that particular feed were as follows

\begin{tabular}{|l|c|}
\hline $\begin{array}{l}\text { Name of the major } \\
\text { composition }\end{array}$ & $\begin{array}{l}\text { Amount of composition } \\
(\%)\end{array}$ \\
\hline 1.Moisture & 11.75 \\
\hline 2. Ash & 10.34 \\
\hline 3. Protein & 20.71 \\
\hline 4. Lipid & 8.64 \\
\hline 5. Fiber & 5.35 \\
\hline 6. Carbohydrates & 43.21 \\
\hline
\end{tabular}

\section{Selected fishes used for experiment}

Small koi (Anabas testudineus) fishes were used for this experiment. Average body length of each fish was $7.5 \mathrm{~cm}$. Average body weight of each fish was $5 \mathrm{~g}$. 20 fishes were used for each aquarium. Total numbers of fishes used for 10 aquariums were $10 * 20=200$.

\section{Selected groups of growth promoters}

Growth promoters were selected through personal contract with the area manager and reprehensive of different pharmaceuticals companies. Different drugs were also collected from direct contract with the medical promoting officers of different pharmaceutical companies such as- EON, NOVARTIS, RENATA.

Selected growth promoters were the followings

A. Trade name: - Nuricell-Aqua.

Composition: Glucomannan complex and

Mannosepolymer.

Company name:-EON.

Manufactured by:-AB/MAURI

Price.Tk:-275/500g

Present form: - Powder

Mixing rate:-0.25-0.5/kg fish feed

B .Trade name:-Aqua-boost

Composition:-Selected organic acid and their salt.

- Beta_Glucan

-Essential oil

-Mannon Oligosecharide.

Company name:-Novartis

Manufactured by:-Bizant Chemic India

Price.Tk:-110/250gm

Present form:-Powder

C. Trade name:-Hepaprotect-Aqua.

Composition: - Beta_Glucan

-Mannon Pplymer

-Essential oil

Company name:-Renata

Manufactured by:-Biomin

Price.Tk:-65/100kg

Present form:-Powder

Mixing rate:-100-200g/100kg of fish feed

\section{Trials of growth promoters and feeds}

A trial of feeds and growth promoters were conducted in 9 aquariums, but only feeds with out any growth promoters were conducted in the control aquarium.The trial was conducted for 20 days. After every 7 days of the experiments, the weight if every aquarium's fishes were estimated or calculated carefully by electric/normal balance.

\section{Experimental setup}

The growth promoter "Nutricell-aqua" with fish feed was given in first three aquariums and the next three aquariums were given with growth promoter "Aquaboost" with fish feed. After that, next three aquariums were also given with growth promoter "Hepaprotectaqua" with fish feed. The last aquariums were given for the control. This control aquarium, were given with only fish feed with out any growth promote. Each 
three separate aquarium were designated as section $\mathrm{A}$, section $\mathrm{B}$, section $\mathrm{C}$ and control respectively. Every aquarium were given fish feed according to their $20 \%$ body weight.

\section{COMBINATION:-}

\section{SECTION (A):}

Growth promoter "Nutricell-aqua"Aquarium-1:Recommended dose:-10mg drug with $20 \mathrm{~g}$ feed/day. Aquarium-2:-Higher dose:-15mg drug with $20 \mathrm{~g}$ feed/day.Aquarium-3:-Lower dose:-5mg drug with $20 \mathrm{gfeed} /$ day.

\section{SECTION (B):}

Growth promoter "Aqua-boost”Aquarium-4:Recommended dose:-10mg drug with $20 \mathrm{~g}$ feed/day. Aquarium-5:-Higher dose:-15mg drug with $20 \mathrm{~g}$ feed/day.Aquarium-6:-Lower dose:-5mg drug with 20 gfeed/day.

\section{SECTION(C):}

Growth promoter "Hepaprotect-aqua"Aquarium-7:Recommended dose:-40mg drug with $20 \mathrm{~g}$ feed/day.Aquarium-8:-Higher dose:-60mg drug with $20 \mathrm{~g}$ feed/day.Aquarium-9:-Lower dose:-20mg drug with $20 \mathrm{gfeed} /$ day.

CONTROL:-Only fish feed with any drugs.Aquarium10:-20gm fish feed/day.

\section{Calculation and application:-}

The experiment was conducted with the mixture of drugs and fish feed. Every day individual aquarium was must be supplied growth promoters bearing fish feed with $20 \%$ body weight of fishes.

Feed required for each aquarium per day:-with $20 \%$ body weight.

Here, total weight in each aquarium was $100 \mathrm{~g}$.

So, $100 \mathrm{~g}$ fish require $20 \mathrm{~g}$ feed

$1 \mathrm{~g}$ fish require $20 * 100$

$100 \mathrm{~g}$ fish require $20 * 100 / 100=20 \mathrm{~g}$ feeds

So, every aquarium required $20 \mathrm{~g}$ fish feeds.

\section{SECTION:-A}

Calculation of recommended, higher, and lower dose for "Neutricell-aqua":-
Company dose:- $1 \mathrm{~kg}$ feed with $0.5 \mathrm{~g}$ drug.

$1000 \mathrm{~g}$ feed mixed with $0.5 \mathrm{~g}$ drug $1 \mathrm{~g}$ feed mixed with $0.5 / 1000 \mathrm{~g}$ drug $20 \mathrm{~g}$ feed mixed with $0.5 * 20 / 1000=0.01 \mathrm{~g}=10 \mathrm{mg}$ drug.

So,

Aquarium.1: Recommended dose $=10 \mathrm{mg}$ drug with $20 \mathrm{~g}$ feed/day

Aquarium.2: Higher dose $=15 \mathrm{mg}$ drug with $20 \mathrm{~g}$ feed/day

Aquarium.3: Lower dose $=5 \mathrm{mg}$ drug with $20 \mathrm{~g}$ feed/day

\section{SECTION:-B}

Calculation of recommended, higher, and lower dose for "Aqua-boost":-

Company dose:-1000kg feed with $500 \mathrm{~g}$ drug. $1000000 \mathrm{~g}$ feed mixed with $500 \mathrm{~g}$ drug $1 \mathrm{~g}$ feed mixed with 500/1000000g drug $20 \mathrm{~g}$ feed mixed with $500 * 20 / 1000000=0.01 \mathrm{~g}=10 \mathrm{mg}$ drug.

So, Aquarium.4: Recommended dose $=10 \mathrm{mg}$ drug with $20 \mathrm{~g}$ feed/day

Aquarium.5: Higher dose $=15 \mathrm{mg}$ drug with $20 \mathrm{~g}$ feed/day feed/day

Aquarium.6: Lower dose $=5 \mathrm{mg}$ drug with $20 \mathrm{~g}$

\section{SECTION:-C}

Calculation of recommended, higher, and lower dose for "Hepaprotect-aqua":-

Company dose:-100kg feed with $200 \mathrm{~g}$ drug. $100000 \mathrm{~g}$ feed mixed with $200 \mathrm{~g}$ drug $1 \mathrm{~g}$ feed mixed with 200/100000g drug $20 \mathrm{~g}$ feed mixed with $200 * 20 / 100000=0.04 \mathrm{~g}=40 \mathrm{mg}$ drug.

So, Aquarium.7: Recommended dose $=40 \mathrm{mg}$ drug with $20 \mathrm{~g}$ feed/day

Aquarium.8: Higher dose $=60 \mathrm{mg}$ drug with $20 \mathrm{~g}$ feed/day

Aquarium.9: Lower dose $=20 \mathrm{mg}$ drug with $20 \mathrm{~g}$ feed/day

\section{CONTROL:}

Only $20 \mathrm{~g}$ feed required for the control aquarium. So, Aquarium.10: Only $20 \mathrm{~g}$ feed/day 


\section{Results}

After the starting of this study weight gain after 7, 14, 20 days were calculated by electrical balance. Varieties of result were measured from this calculation. These are as describe as below:-

Table: 1. Results of feeding trial incase of "nutricell-aqua" growth promoter.

\begin{tabular}{|c|c|c|c|c|c|c|c|}
\hline $\begin{array}{l}\text { Name of the } \\
\text { company and } \\
\text { their product }\end{array}$ & $\begin{array}{ll}\text { No. } \\
\text { aquarium }\end{array}$ & $\begin{array}{l}\text { Selected } \\
\text { dose }\end{array}$ & $\begin{array}{l}\text { Initial weight } \\
\text { of fishes }(\mathrm{g})\end{array}$ & $\begin{array}{l}\text { Weight of } \\
\text { fishes after } 7 \\
\text { days }(\mathrm{g})\end{array}$ & $\begin{array}{l}\text { Weight of } \\
\text { fishes after } \\
14 \text { days }(\mathrm{g})\end{array}$ & $\begin{array}{l}\text { Weight of } \\
\text { fishes after } \\
20 \text { days }(\mathrm{g})\end{array}$ & $\begin{array}{l}\text { Total weight } \\
\text { gain of } \\
\text { fishes after } \\
20 \text { days }(\mathrm{g})\end{array}$ \\
\hline \multirow{3}{*}{$\begin{array}{l}\text { NUTRIC } \\
\text { ELL-AQUA } \\
\text { "EON" }\end{array}$} & $\begin{array}{l}\text { Aquarium } \\
\text { (1) }\end{array}$ & $\begin{array}{l}\text { Recommend } \\
\text { ed dose } \\
10 \mathrm{mg} / 20 \text { gfee } \\
\text { d/day }\end{array}$ & 100 & 110 & 120.75 & 130.25 & 30.25 \\
\hline & $\begin{array}{l}\text { Aquarium } \\
\text { (2) }\end{array}$ & $\begin{array}{l}\text { Higher dose } \\
15 \mathrm{mg} / 20 \mathrm{~g} \\
\text { feed/day }\end{array}$ & 100 & 120 & 130.15 & 130.85 & 30.85 \\
\hline & $\begin{array}{c}\text { Aquarium } \\
\text { (3) }\end{array}$ & $\begin{array}{l}\text { Lower dose } \\
5 \mathrm{mg} / 20 \mathrm{~g} \\
\text { feed/day }\end{array}$ & 100 & 100 & 110.10 & 110.25 & 10.25 \\
\hline
\end{tabular}

Table : 2. Results of feeding trial in case of "Aqua-boost" growth promoter.

\begin{tabular}{|c|c|c|c|c|c|c|c|}
\hline $\begin{array}{l}\text { Name of the } \\
\text { company and } \\
\text { their product }\end{array}$ & $\begin{array}{l}\text { No. of } \\
\text { aquarium }\end{array}$ & Selected dose & $\begin{array}{l}\text { Initial weight } \\
\text { of fishes }(\mathrm{g})\end{array}$ & $\begin{array}{l}\text { Weight of } \\
\text { fishes after } 7 \\
\text { days }(\mathrm{g})\end{array}$ & $\begin{array}{l}\text { Weight of } \\
\text { fishes after } \\
14 \text { days }(\mathrm{g})\end{array}$ & $\begin{array}{l}\text { Weight of } \\
\text { fishes after } \\
20 \text { days }(\mathrm{g})\end{array}$ & $\begin{array}{l}\text { Total weight } \\
\text { gain of } \\
\text { fishes after } \\
20 \text { days }(\mathrm{g})\end{array}$ \\
\hline \multirow[b]{2}{*}{$\begin{array}{l}\text { AQUA- } \\
\text { BOOST }\end{array}$} & $\begin{array}{l}\text { Aquarium } \\
\text { (4) }\end{array}$ & $\begin{array}{l}\text { Recommended } \\
\text { dose } \\
10 \mathrm{mg} / 20 \mathrm{gfeed} \\
/ \text { day }\end{array}$ & 100 & 120 & 140 & 150 & 50 \\
\hline & $\begin{array}{l}\text { Aquarium } \\
\text { (5) }\end{array}$ & $\begin{array}{l}\text { Higher dose } \\
15 \mathrm{mg} / 20 \mathrm{~g} \\
\text { feed/day }\end{array}$ & 100 & 140 & 180 & 190.50 & 90.50 \\
\hline "NOVARTIS & $\begin{array}{c}\text { Aquarium } \\
\text { (6) }\end{array}$ & $\begin{array}{l}\text { Lower dose } \\
5 \mathrm{mg} / 20 \mathrm{~g} \\
\text { feed/day }\end{array}$ & 100 & 110 & 120.50 & 120.75 & 20.75 \\
\hline
\end{tabular}

Table : 3 Results of feeding trial incase of "Hepaprotect-aqua" growth promoter.

\begin{tabular}{|c|c|c|c|c|c|c|c|}
\hline $\begin{array}{l}\text { Name of the } \\
\text { company and } \\
\text { their product }\end{array}$ & $\begin{array}{ll}\text { No. } & \text { of } \\
\text { aquarium }\end{array}$ & $\begin{array}{l}\text { Selected } \\
\text { dose }\end{array}$ & $\begin{array}{l}\text { Initial } \\
\text { weight of } \\
\text { fishes }(\mathrm{g})\end{array}$ & $\begin{array}{l}\text { Weight of } \\
\text { fishes after } \\
7 \text { days }(\mathrm{g})\end{array}$ & $\begin{array}{l}\text { Weight of } \\
\text { fishes after } \\
14 \text { days }(\mathrm{g})\end{array}$ & $\begin{array}{l}\text { Weight of } \\
\text { fishes after } \\
20 \text { days }(\mathrm{g})\end{array}$ & \begin{tabular}{lr}
\multicolumn{2}{l}{ Total } \\
weight gain \\
of fishes \\
after 20 \\
days $(\mathrm{g})$ \\
\end{tabular} \\
\hline \multirow[b]{2}{*}{$\begin{array}{l}\text { HEPAPROTE } \\
\text { CT-AQUA }\end{array}$} & $\begin{array}{l}\text { Aquarium } \\
\text { (7) }\end{array}$ & $\begin{array}{l}\text { Recommend } \\
\text { ed dose } \\
40 \mathrm{mg} / 20 \mathrm{gfe} \\
\text { ed/day }\end{array}$ & 100 & 130 & 140 & 140.75 & 40.75 \\
\hline & $\begin{array}{c}\text { Aquarium } \\
\text { (8) }\end{array}$ & $\begin{array}{l}\text { Higher dose } \\
60 \mathrm{mg} / 20 \mathrm{~g} \\
\text { feed/day }\end{array}$ & 100 & 120 & 130 & 130.50 & 30.50 \\
\hline "RENATA" & $\begin{array}{c}\text { Aquarium } \\
\text { (9) }\end{array}$ & $\begin{array}{l}\text { Lower dose } \\
20 \mathrm{mg} / 20 \mathrm{~g} \\
\text { feed/day }\end{array}$ & 100 & 110 & 110.50 & 110.75 & 10.75 \\
\hline
\end{tabular}




\section{Control}

In case if control aquarium namely (10), only fish feed with out any growth promoters were supplied into this aquariam. In case of control aquarium, holding number was (10). Initial weight of fishes was $100 \mathrm{~g}$, weight of fishes after 7 days, 14 days, and 20 days were $110.15 \mathrm{~g}, 100.35 \mathrm{~g}$, and $100.40 \mathrm{~g}$ respectively. After 20 days feeding trial control aquarium's performances was not so better than the other aquarium.

Table 4. Results of feeding trial in case of control aquarium

\begin{tabular}{|l|l|l|l|l|l|l|c|}
\hline $\begin{array}{l}\text { Name of } \\
\text { company } \\
\text { and their } \\
\text { products }\end{array}$ & $\begin{array}{l}\text { No. of } \\
\text { aquarium }\end{array}$ & Selected dose & $\begin{array}{l}\text { Initial weight of } \\
\text { fishes }\end{array}$ & $\begin{array}{l}\text { Weight of } \\
\text { fishes after 7 } \\
\text { days }\end{array}$ & $\begin{array}{l}\text { Weight of } \\
\text { fishes after 14 } \\
\text { days }\end{array}$ & $\begin{array}{l}\text { Weight of } \\
\text { fishes after 20 } \\
\text { days }\end{array}$ & $\begin{array}{l}\text { Total weight } \\
\text { gain of fishes } \\
\text { after 20 days }\end{array}$ \\
\hline CONTROL & $\begin{array}{c}\text { Aquarium } \\
(10)\end{array}$ & $\begin{array}{l}\text { Only 20g } \\
\text { feed/day }\end{array}$ & 100 & 100.15 & 100.35 & 100.40 & 0.40 \\
\hline
\end{tabular}

Table 5. Comparative study between three growth promoters and control aquarium.

\begin{tabular}{|c|c|c|c|}
\hline Name of company & Initial weight of fishes(g) & $\begin{array}{l}\text { Total weight gain of fishes after } \\
\text { 20 days feeding trial }\end{array}$ & Comments \\
\hline EON & 100 & 71.35 & Lower \\
\hline NOVARTIS & 100 & 161.25 & Very good /Higher \\
\hline RENATA & 100 & 82 & Medium \\
\hline CONTROL & 100 & 0.40 & Lowest \\
\hline
\end{tabular}

\section{Discussion}

The present investigation was conducted to know the efficacy of various growth promoters from some pharmaceutical companies, such as Nutricell-aqua from EON Company, Aqua-boost from_NOVARTIS Company and Hepaprotect-aqua from RENATA Company.The present study was carried out to justify the recommended dose and method of application of particular growth promoter. Some variation was found between the information on the leaflet and packets. Neither the sellers or nor the farmers and extension workers had clear ideas about the ingredients of pharmaceutical companies and they were using those drugs with out any hesitations. In the experiment Nutricell-aqua growth promoters from eon group were tested on koi fish for their efficacy performance to their recommended dose. But higher dose shown a better performance than the recommended and lower dose. So, the company should be aware about their recommended dose making. On the other hand "Aquaboost" growth promoter from novartis group was also tested for their efficacy performances on koi fish into aquarium. Results of their recommended dose were comfortable but the performance of higher dose was very much higher than the other dose. So, this company should also be aware about the selection of their recommended dose. Another growth promoter "Hepaprotect-aqua" from renata group were also tested for their efficacy performance. In case of this study company's recommended dose scored a better result than the other, higher and lower dose. So, this company should not be worried about their recommended dose.The performances of growth in case of control aquarium were very much light or poor /slight compared with the other aquarium. So, it is important to apply proper growth promoters and best application method for aqua-production management. Pharmaceutical companies should conduct more and more research and development towards reducing the harmful impact of aqua-medicine in aquaculture of country like Bangladesh.

\section{Conclusion}

Three selected drug were Nutrecell-aqua, Aqua-boost, Hepaprotect-aqua. For each drug three dosage as recommended, higher than recommended and lower than recommended were used to access the safe and effective dose which give best results than other as well as than the control section. We stocked 20 fish in to a single aquarium and three aquariums were selected for a single drug with recommended, higher, lower dosage and a control aquarium were placed to evaluate the result with it. Aqua-boost were recorded the higher result or growth at higher dose and Hepaprotect-aqua were selected second higher result at recommended rose. Nutricell-aqua scored good result at higher dose but overall result is the poorest than two growth promoters. This study suggests that the growth of fishes varied with different dosage and different time intervals. 


\section{References}

Alderman, D.J., H. Rosenthal, P. Smith, J. Stewart and D. Weston. 1994. Chemicals used in mariculture. ICES Coop. Res. Rep. 202: 100.

Islam, T.M. 2010. Effects of chemotherapeutics against Aeromonas hydrophila infection in climbing perch Anabas testudineus. MS Thesis. Department of Aquaculture, BAU, Mymensingh. 46pp.

Islam, T.M. 2010. Present status of aqua-medicines used in aqua health management. MS
Thesis. Department of Aquaculture, BAU, Mymensingh. 35pp.

Subasinghe, R.P., U. Barg and A. Tacon. 1996. Chemicals in Asian aquaculture: need, usage, issues and challenges. In: Use of Chemicals in Aquaculture in Asia.Arthur, J.R., C.R. Lavilla-pitogo, R. P Subasinghe (eds). Southeast Asian Fisheries Development Center, Aquaculture Department Tigbauan,Iloilo, Philippines,pp1.

Mixing rate:-500g/ton of fish feed. 